\title{
FWD によるコンクリート舗装の空洞検出方法
}

\author{
河村 直哉 ${ }^{1} \cdot$ 坪川 将丈 ${ }^{2} \cdot$ 加藤 $^{\text {絵万 }}{ }^{3}$ \\ 1正会員 国土交通省 国土技術政策総合研究所 空港研究部 空港施設研究室 \\ （干239-0826 神奈川横須賀市長瀬3-1-1) \\ E-mail: kawamura-n92y2@mlit.go.jp \\ 2正会員 国土交通省 国土技術政策総合研究所 空港研究部 空港施設研究室（同上） \\ E-mail: tsubokawa-y92y2@mlit.go.jp \\ 3 正会員 海上・港湾・航空技術研究所 港湾空港技術研究所 構造研究領域 構造研究グループ (同上) \\ E-mail: katoh-e@pari.go.jp
}

FWD（Falling Weight Deflectometer）で得られるコンクリート舗装の応答から，コンクリート版下の空洞 を検出する方法を提案することを目的として，空洞を有する空港および港湾施設のコンクリート舗装にお いてFWD調査を実施し，コンクリート版下の空洞が舗装の忘答に及ぼす影響を分析した。 その結果に基づ き, 空洞を検出する指標として, 正規化たわみ（載荷板中心と載荷板中心から離れた点の最大たわみの比） とたわみ時間差 (載荷板中心と載荷板中心から離れた点のたわみが最大となる時間差) の2指標を提案する. これらの指標を複合的に用いる空洞検出方法は, 版中央部, 目地部, 隅角近傍部および隅角部に適用でき ると考えられる.

Key Words : concrete pavement, void, FWD, deflection

\section{1. はじめに}

地震発生後の空港舗装では, 基礎地盤の液状化や切土・ 盛土境界部の変形に伴い空洞が発生することがある1),2). コンクリート舗装に空洞が生じた場合，広範囲の空洞で あればコンクリート版（以下，版）がその自重で沈下す るものの ${ }^{1)}$, 空洞の規模によっては表面に変状が表れな い場合もある ${ }^{3)}$ ．航空機等が表面に変状のない空洞化箇 所を走行すると，突発的に宿没する危険性があるため， 地震発生後に液状化等が確認された場合には, 舗装の支 持力を評価するとともに, 舗装における空洞の有無や位 置を把握することが重要である.

舗装の支持力評価はFWD (Falling Weight Deflectometer) で可能であり4)，空洞の検出は地中レーダで可能である5) しかしながら, 地震後の空港は早期の運用再開を求めら れ，時間的制約を踏まえると，FWDと地中レーダ双方の 機器を準備して調査を実施することは容易でない，その ため, FWDによって，支持力を評価することに加えて空 洞を検出できることが望まれる.

FWDによる空洞検出方法として，八谷られは，空洞幅 の増加に伴い載荷板中心の最大たわみ（以下， $D_{0}$ ) が大 きくなることに着目して, 空洞箇所と非空洞箇所の $D_{0} の$
比によって空洞幅を推定する方法を提案している.また, Zengら》は，コンクリート舗装に発生する理論たわみを 解析的に求め, 解析で求めた $D_{0}$ に対寸る実測の $D_{0}$ の比に 基づいて空洞の有無を判定する方法を提案している. そ の一方で，D泪，ひび割れ等空洞以外の要因でも大きく なることや同一舗装断面であっても構成材料や層厚のば らつきに起因してばらつくため8)，空洞の有無の情報が ない状態では, $D_{0}$ のみでの空洞検出は困難であるという 指摘がある9．以上のように，これまでにFWDによる空 洞検出方法を検討した研究は数例あり，いずれも $D_{0}$ に基 づく方法であるが，その検出精度には限界があると考え られる.

そこで本研究は, FWDによる新たな空洞検出方法を提 案することを目的として，まず，版下に空洞がある可能 性の高いコンクリート舗装においてFWD調查を実施し, 版下の空洞が舗装の応答に及ぼす影響を分析した．その 結果，正規化たわみ（載荷板中心と載荷板中心から離れ た点の最大たわみの比）とたわみ時間差（載荷板中心と 載荷板中心から離れた点のたわみが最大となる時間差) が，空洞の存在により影響を受ける指標である可能性を 示した. 次に, 空洞の平面分布が既知の舗装において, これら2指標の空洞検出指標としての適用性を検証した. 


\section{2. 版下の空洞がコンクリート舗装の FWD 応答に 及ぼす影響の分析}

本章では，版下に空洞がある可能性の高い場所におい て実施した FWD 調査の結果を分析し，空洞検出に適用 できる可能性のある指標を検討する.

\section{(1) FWD 調査場所}

調査を実施した舗装は，仙台空港のエプロンの無筋コ ンクリート舗装である. 版の寸法は 1 辺 $7.5 \mathrm{~m}$ の正方形 であり，厚さは $0.42 \mathrm{~m}$ である．路盤は粒度調整砕石によ り構築され，設計支持力係数は $70 \mathrm{MN} / \mathrm{m}^{3}$ であった. 目地 にはダウエルバーやタイバーが設置されている.

図-1に，エプロンの高さとひび割れ発生位置を記載し たエプロン平面図を示す. 舗装施工当初より，15 列と 16 列の版の目地を境として北側および南側に向けて $0.5 \%$ の下り勾配が確保されているが，地震時の液状化によっ て版は局所的に沈下し，それに伴いひび割れが生じた。

沈下は，DD3，D6，F3 および K9 付近で確認された. F3 と K9 においてコアボーリング（直径 $100 \mathrm{~mm}$ ) により 削孔調査を行ったところ，厚さ約 $0.07 \mathrm{~m}$ と約 $0.20 \mathrm{~m}$ の空 洞が版直下に確認されたため，沈下部付近の版直下には 空洞があることが示唆される.

FWD 調査は，ひび割れや沈下が確認された版を中心 に, 航空機が駐機する範囲で実施した (図-1の破線範囲).

\section{(2) FWD 調査方法}

\section{a) 載荷条件}

載荷板直径は $0.3 \mathrm{~m}$ であり, 載荷荷重は $200 \mathrm{kN}$ である. 載荷は同一位置にて 4 回行い, 時刻歴 (測定間隔 $0.25 \mathrm{~ms}$ ) でたわみを計測した。なお，載荷 1 回目のデータについ ては，載荷板やたわみセンサと路面の接触不安定により 測定のばらつきが大きいため ${ }^{10)}$, 棄却し, 2〜4 回目のデ 一タを平均化した.たわみの測定点 (以下, 測定点) は, 載荷板中心，中心より 200，300，450，600，750，900, 1200，1500 および $2500 \mathrm{~mm}$ である.

\section{b) 載荷板設置位置}

載荷板の設置位置は版中央部とした。たわみセンサの 配置方向は北向きとした.

\section{(3) 分析データの選定}

空洞の平面的な分布は不明である，そこで，版下に空 洞がある可能性の高い版と低い版を, 沈下量と補正 $D_{0}$ が 相対的に大きい版および小さい版という視点で選定した。 補正 $D_{0}$ とは， $D_{0}$ と載荷荷重の各平均值から，載荷荷重 を $200 \mathrm{kN}$ とした場合のたわみに補正した值である.

空洞のある可能性が高い版として, 沈下量と補正 $D_{0}$ が 相対的に大きい版のうち, 載荷板やたわみセンサ付近に ひび割れのない 20 枚を選定した（以下，沈下版群).

空洞のある可能性が低い版として, 沈下量と補正 $D_{0}$ が 相対的に小さい版のうち，載荷板やたわみセンサ付近に ひび割れのない 20 枚を選定した（以下，非沈下版群）.

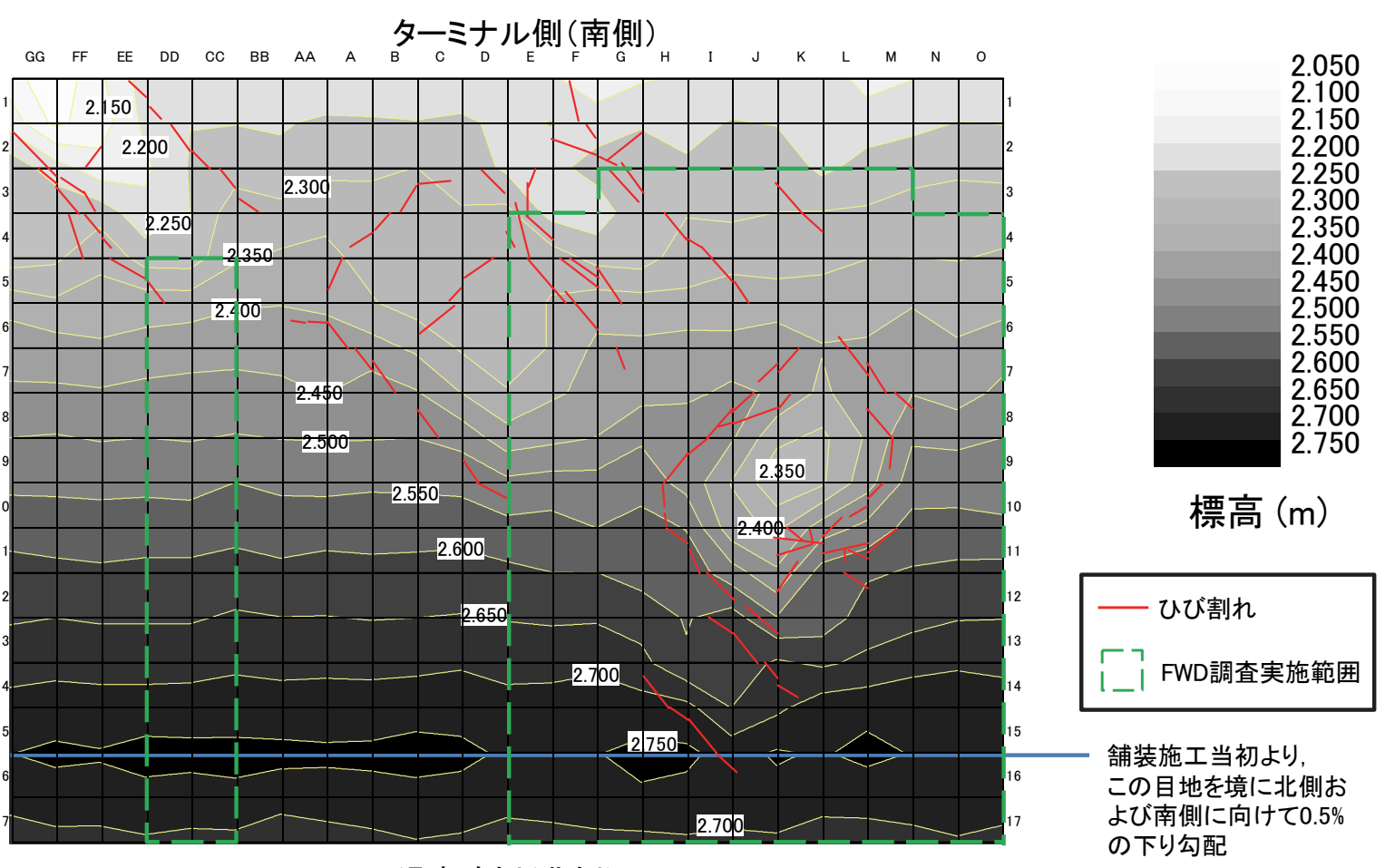

滑走路側 (北側)

図-1 エプロンの高さおよびひび割れ発生位置 1) (升目は一枚のコンクリート版を示す) 
図-2 に，調査した全ての版の沈下量と補正 $D_{0}$ の関係 を示し，そのうち，選定した版は丸と四角で示す. 四の 解析 $D_{0}$ は，FEM 解析プログラム CPfor で得た $D_{0}$ であ る. 解析条件は, 版厚 $0.42 \mathrm{~m}$, 版の弾性係数 $34,000 \mathrm{MPa}$, 路盤支持力 $70 \mathrm{MN} / \mathrm{m}^{3}$ ，載荷荷重 $200 \mathrm{kN}$ ，載荷直径 $0.3 \mathrm{~m}$ である。

なお，調査中の気温差は小さかったことから（6.1 ${ }^{\circ} \mathrm{C} 〜$ $\left.9.6^{\circ} \mathrm{C}\right)$, 沈下版群と非沈下版群では, 温度勾配とそれに伴 う反りの程度に大差はないと考えられる，そのため，両 群のたわみを比較するにあたっては，版ごとの温度勾配 が異なることによるたわみの温度補正を行っていない.

\section{(4) FWD による沈下版群と非沈下版群の応答分析 a) 分析項目}

沈下版群と非沈下版群の調査結果を種々の項目で整理 した結果, 分析には 2 指標を用いることとした. 1 つは, たわみ形状に着目した正規化たわみであり，載荷板中心 の最大たわみに対する，載荷板中心から $x \mathrm{~mm}$ の最大た わみの比である. 式(1)に正規化たわみの定義を示す.

$$
N D_{x}=D_{x} / D_{0}
$$

ここに

$N D_{x}$ ：載荷板中心から $x \mathrm{~mm}$ の測定点の正規化たわみ

$D_{x}$ ： 載荷板中心から $x \mathrm{~mm}$ の測定点の最大たわみ( $\left.\mu \mathrm{m}\right)$

$D_{0}: \quad$ 載荷板中心の最大たわみ $(\mu \mathrm{m})$

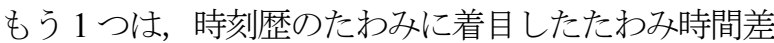
であり，載荷板中心のたわみが最大となる時間と載荷板 中心から $x \mathrm{~mm}$ のたわみが最大となる時間の差である. 式(2)および図-3に，たわみ時間差の定義を示す.

$$
\Delta t_{x}=t_{x}-t_{0}
$$

ここに,

$\Delta t_{x}$ : 載荷板中心から $x \mathrm{~mm}$ の測定点のたわみ時間差(ms)

$t_{x}$ : 載荷板中心から $x \mathrm{~mm}$ の測定点のたわみが最大とな る時間 (ms)

$t_{0}$ : 載荷板中心のたわみが最大となる時間 $(\mathrm{ms})$

b) 分析結果

図-4 に，載荷板中心から測定点までの距離と正規化た わみの関係を示す。図では，沈下版群と非沈下版群の結 果を比較しやすくするために，両群の各プロットを，実 際の測定点までの距離から左右にずらして記載した。

測定点までの距離によらず，沈下版群の正規化たわみ の平均值は，非沈下版群よりも大きかった．特に沈下版 群では，正規化たわみ $N D_{200}$ と $N D_{300}$ が 1.0 以上である 版（ $D_{200}$ や $D_{300}$ が $D_{0}$ より大きい版）が多く確認された.
図-5に，載荷板中心から測定点までの距離とたわみ時 間差の関係を示す．測定点までの距離によらず，たわみ 時間差の平均值は，沈下版群の方が小さかった。空洞が ある版では，載荷板から離れた測定点のたわみが大きく なるだけでなく，たわみ時間差が小さくなる可能性があ る.

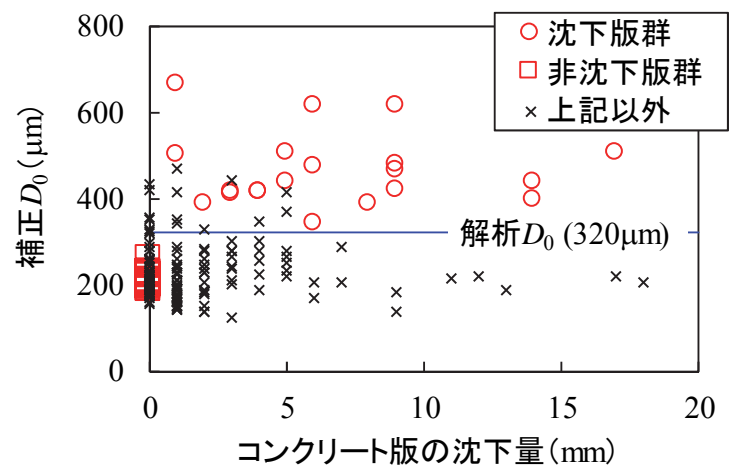

図-2 沈下量と補正 $D_{0}$ の関係

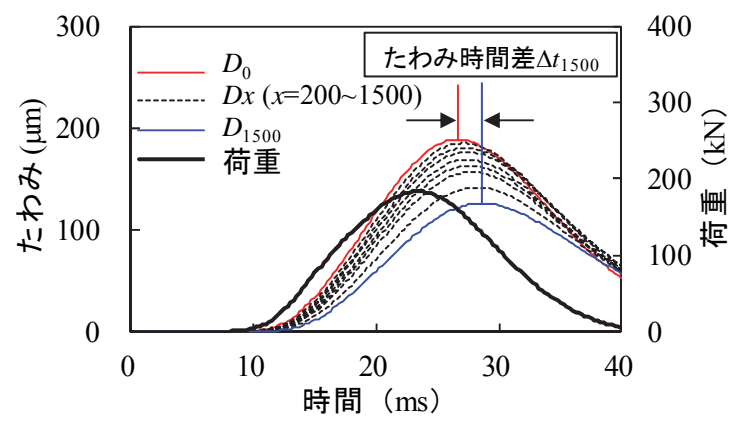

図-3 たわ夕時間差の定義（ $\Delta t_{1500}$ の場合）
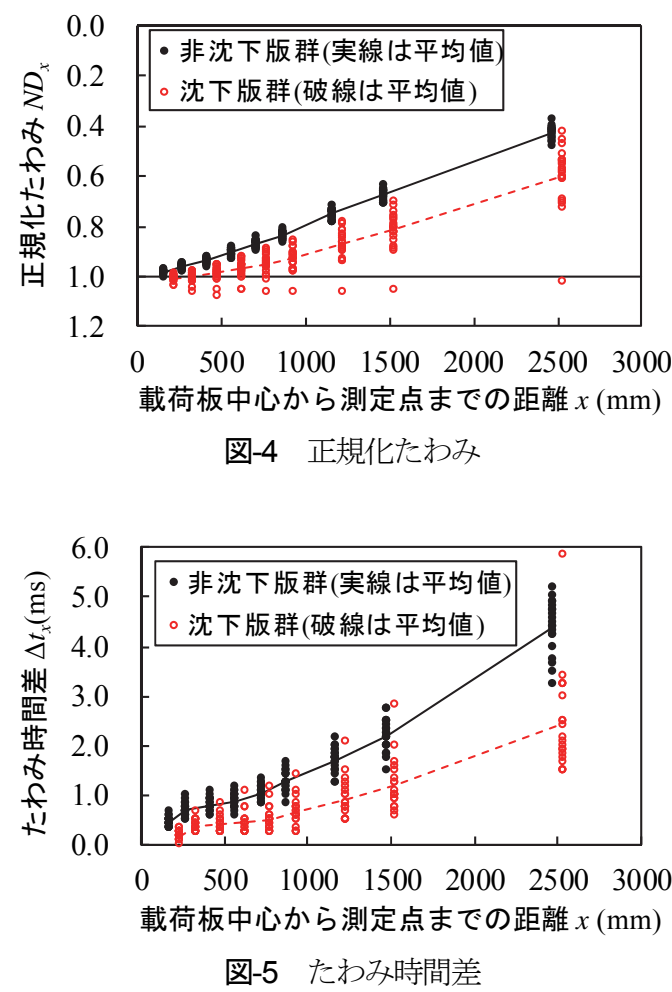

図-5 たわ久時間差 
図-6 に，測定点 $300 \mathrm{~mm}$ および $1500 \mathrm{~mm}$ における正規 化たわみとたわみ時間差の関係を一例として示す. どち らの測定点でも沈下版群と非沈下版群の分布に違いが確 認された。 また，図-4 や図-5 のように単指標で沈下版群 と非沈下版群を比較した場合，両群の分布が重なってい た一方で，図-6に示した 2 指標による比較では分布は殆 ど重なっていない.

なお，本調査では，沈下版群と非沈下版群の温度勾配 は同程度であると考えられるため, 版に反りが発生して いれば，両群で発生していたこととなり，図-6に示した 両群の分布は重なると考えられる. しかし，分布は明確 に分かれているため，版の反りが 2 指標に及ぼす影響は 小さいと考えられる.

\section{c）分析結果に関する検定}

沈下版群と非沈下版群間の正規化たわみの平均差およ びたわみ時間差の平均差が有意であることを確認するた めに，統計的検定を行った．検定では帰無仮説を「沈下 版群と非沈下版群の平均值に差がない」として，母集団 の分布を仮定しない Mann-Whitney’s U 検定（両側検定， 有意水準 5\%，以下，検定）を行った．表-1 に検定結果 を示す．全測定点において，正規化たわみの平均差およ びたわタ時間差の平均差は有意であった。

以上の分析および検定結果より，正規化たわみやたわ み時間差は，空洞の検出指標として適用できる可能性が あり，特に 2 指標の併用がより検出に適している可能性 がある。

なお，沈下版群と非沈下版群の結果に差が明確に表れ た要因として, 空洞がある可能性の高い箇所 (沈下版群), 空洞がある可能性の低い箇所（非沈下版群）という，両 極端な箇所を分析対象としており，その中間については 分析対象としていないことによる可能性がある.

\section{(5) 正規化たわみとたわみ時間差の空洞検出指標とし ての妥当性考察}

沈下版群の正規化たわみが大きく，たわみ時間差が小 さかった要因は，空洞が発生し路盤の支持力が著しく低 下したことであると考えられる，本節では，上記の因果 関係を解析的に確認する.

\section{a) 解析条件}

解析では，健全な舗装と，版直下の路盤の支持力を著 しく低下させた舗装のモデルを作成し（以下，健全モデ ルと空洞モデル), 動的順解析により FWD 荷重に伴う時 刻歴たわみを求め, 正規化たわみとたわみ時間差を得た。 動的順解析は，動的逆解析プログラム Wave-BALM ${ }^{11)}$ オプションで実施した.

図-7 に解析モデルを示す，健全モデルでは，版厚を前 述の調査場所と同じ $0.42 \mathrm{~m}$ とし，路盤以深は単層とみな した．単層の弾性係数は，調査場所の路盤の設計支持力
係数 $70 \mathrm{MN} / \mathrm{m}^{3}$ から換算した ${ }^{12)}$. それ以外の層特性は, 既 往文献を参考に設定した ${ }^{13)}$. 空洞モデルでは，削孔調査 における空洞厚さを参考に, 健全モデルの版直下 $0.2 \mathrm{~m}$ の 路盤について, 弾性係数, 密度および咸衰係数を $1 \%$ に低 減させた.

入力荷重には, 実際の載荷板半径と荷重波形を用いた.

\section{b) 解析結果}

図-8に解析結果を示す．空洞モデルの正規化たわみは 大きく，たわみ時間差は小さく，前述の FWD 調査結果 と同様の傾向を得た．路盤に空洞が発生した場合，コン クリート版の厚さ，弾性係数，ポアソン比および路盤の 支持力係数より計算される剛比半径が，路盤の支持力低 下により大きくなることから, 荷重の影響範囲は広がる.

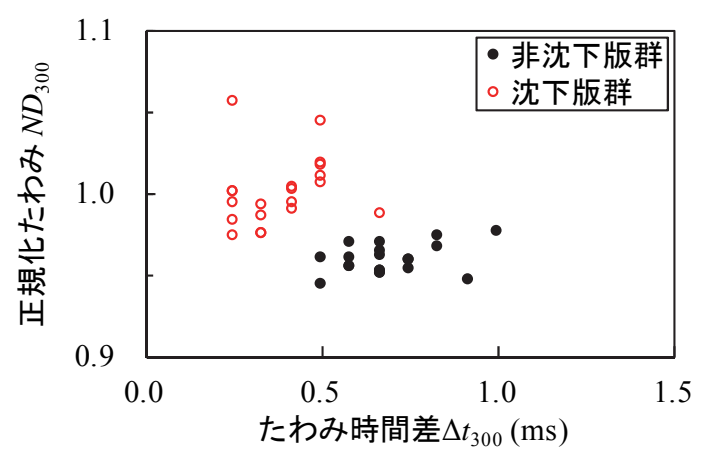

a) 測定点 $300 \mathrm{~mm}$

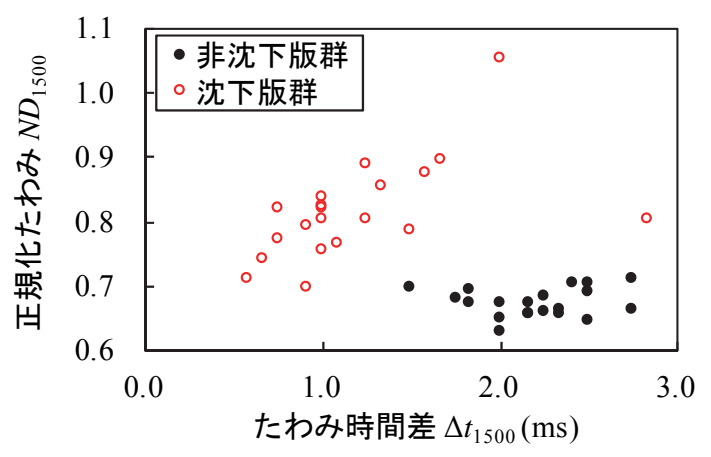

b) 測定点 $1500 \mathrm{~mm}$

図-6 正規化たわみとたわみ時間差の関係

表-1＼cjkstart沈下版群と非沈下版群間の各指標の平均差 に関する検定結果（有意水準 5\%)
a) 正規化たわみ
b) たわみ時間差

\begin{tabular}{|l|l|}
\hline & 検定結果 \\
\hline \hline$N D_{200}$ & p値 $<0.05$ :有意 \\
\hline$N D_{300}$ & p値 $<0.05$ 有意 \\
\hline$N D_{450}$ & p値 $<0.05$ 有意 \\
\hline$N D_{600}$ & p值 $<0.05$ 有意 \\
\hline$N D_{750}$ & p值 $<0.05$ 有意 \\
\hline$N D_{900}$ & p値 $<0.05$ 有意 \\
\hline$N D_{1200}$ & p値 $<0.05$ 有意 \\
\hline$N D_{1500}$ & p値 $<0.05$ 有意 \\
\hline$N D_{2500}$ & p値 $<0.05$ 有意 \\
\hline
\end{tabular}

\begin{tabular}{|c|c|}
\hline & 検定結果 \\
\hline$\Delta t_{200}$ & $\mathrm{p}$ 值 $<0.05$ : 有意 \\
\hline$\Delta t_{300}$ & p值 $<0.05$ : 有意 \\
\hline$\Delta t_{450}$ & p值 $<0.05$ : 有意 \\
\hline$\Delta t_{600}$ & p値 $<0.05$ : 有意 \\
\hline$\Delta t_{750}$ & p值 $<0.05$ : 有意 \\
\hline$\Delta t_{900}$ & p值 $<0.05$ : 有意 \\
\hline$\Delta t_{1200}$ & $\mathrm{p}$ 值 $<0.05$ : 有意 \\
\hline$\Delta t_{1500}$ & p值 $<0.05$ : 有意 \\
\hline$\Delta t_{2500}$ & $\mathrm{p}$ 值 $<0.05$ :有意 \\
\hline
\end{tabular}


これにより，載荷板から離れた位置のたわみの挙動が, 載荷板直下のたわみの挙動に近くなり，正規化たわみは 大きく，たわみ時間差は小さくなると考えられる。

\section{3. 正規化たわみとたわみ時間差の空洞検出指標 としての適用性検証}

空洞位置を明らかにした舗装における調査結果に基づ き，正規化たわみとたわみ時間差の空洞検出指標として の適用性を検証する.

\section{(1) 調査場所}

調査場所は，港湾施設の重力式岸壁のエプロン（全長

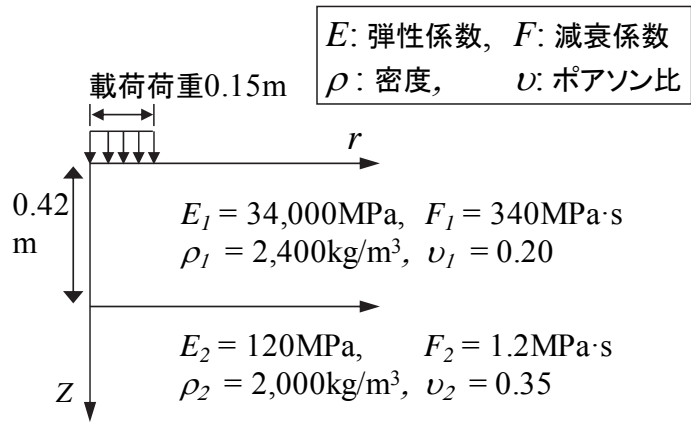

a) 健全モデル

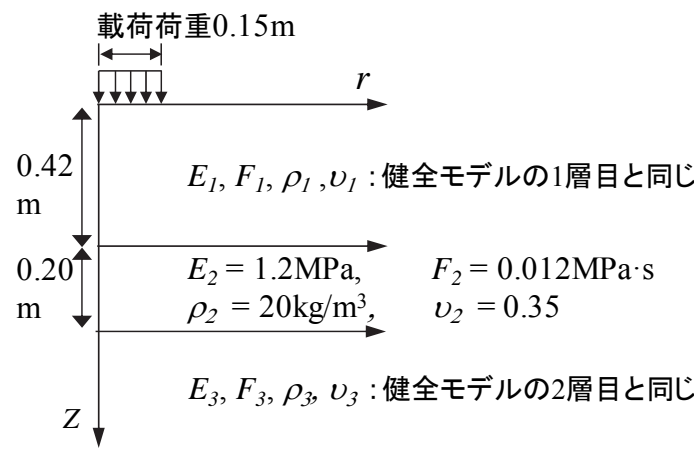

b) 空洞モデル

図-7 解析モデル

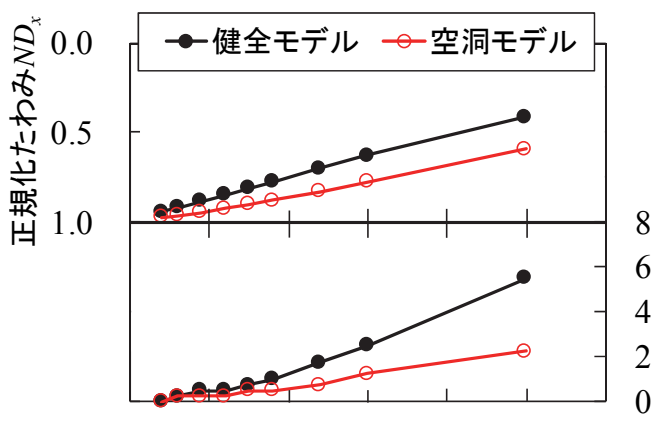

$0 \quad 50010001500200025003000$

載荷板中心から測定点までの距離 $x(\mathrm{~mm})$

図-8 解析で得た正規化たわみとたわみ時間差 400m）である.図-9 に，岸壁の標準断面図とエプロン平 面図の一部を示す．舗装構成はコンクリート版および粒 状路盤である，版厚は約 $0.25 \mathrm{~m}$ であり，路盤の厚さは不 明である. 版の寸法は一辺約 $5.0 \mathrm{~m}$ である. 目地にはダウ エルバーもしくはタイバーが設置されている.

(2) 地中レーダによる空洞探査

\section{a) 探査概要}

探査幅 $2.5 \mathrm{~m}$ の地中レーダ（以下，レーダ）を用いて, エプロン全長の空洞をエプロン海側端部より $12.5 \mathrm{~m}$ から $17.5 \mathrm{~m}$ の範囲で探査した（図-9)。この範囲には，版の目 地が存在するほか，陷没の生じた版があり，他の箇所よ りも空洞が多くある可能性があった。

\section{b) 探査結果}

図-10に，推定された空洞の面積の頻度分布を示す。 多くの空洞が版直下にあり，2 枚以上の版に跨る大きさ の空洞もあった. 本調査では, 図-11に示すとおり, 版直

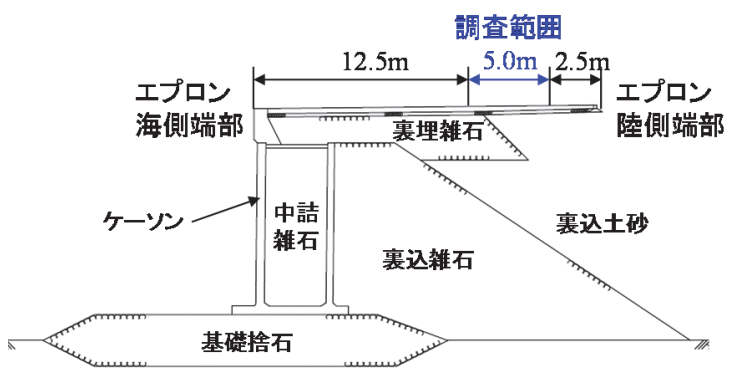

a) 岸壁の標準断面図

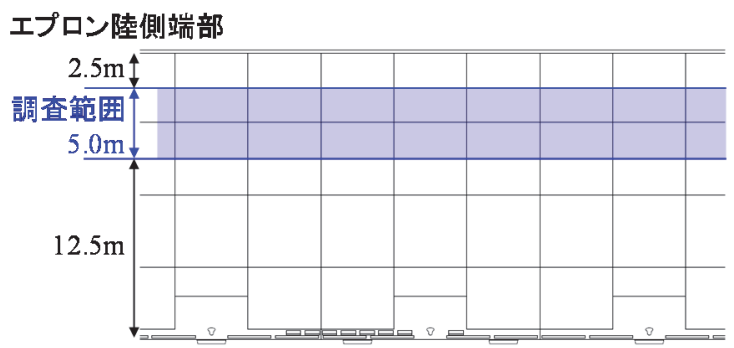

エプロン海側端部

b) エプロン平面図の一部

図-9＼cjkstart調查した岸壁の標準断面図とエプロン平面図

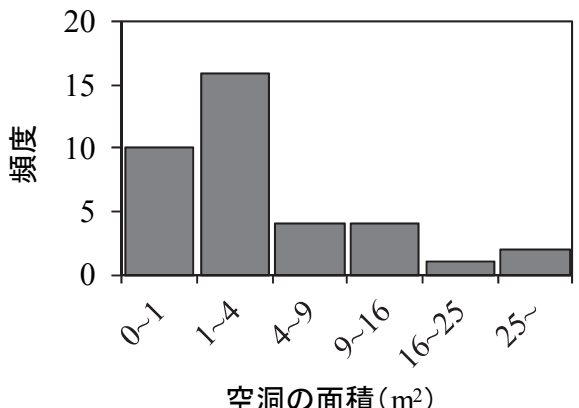

図-10 レーダで推定された空洞面積の頻度分布 

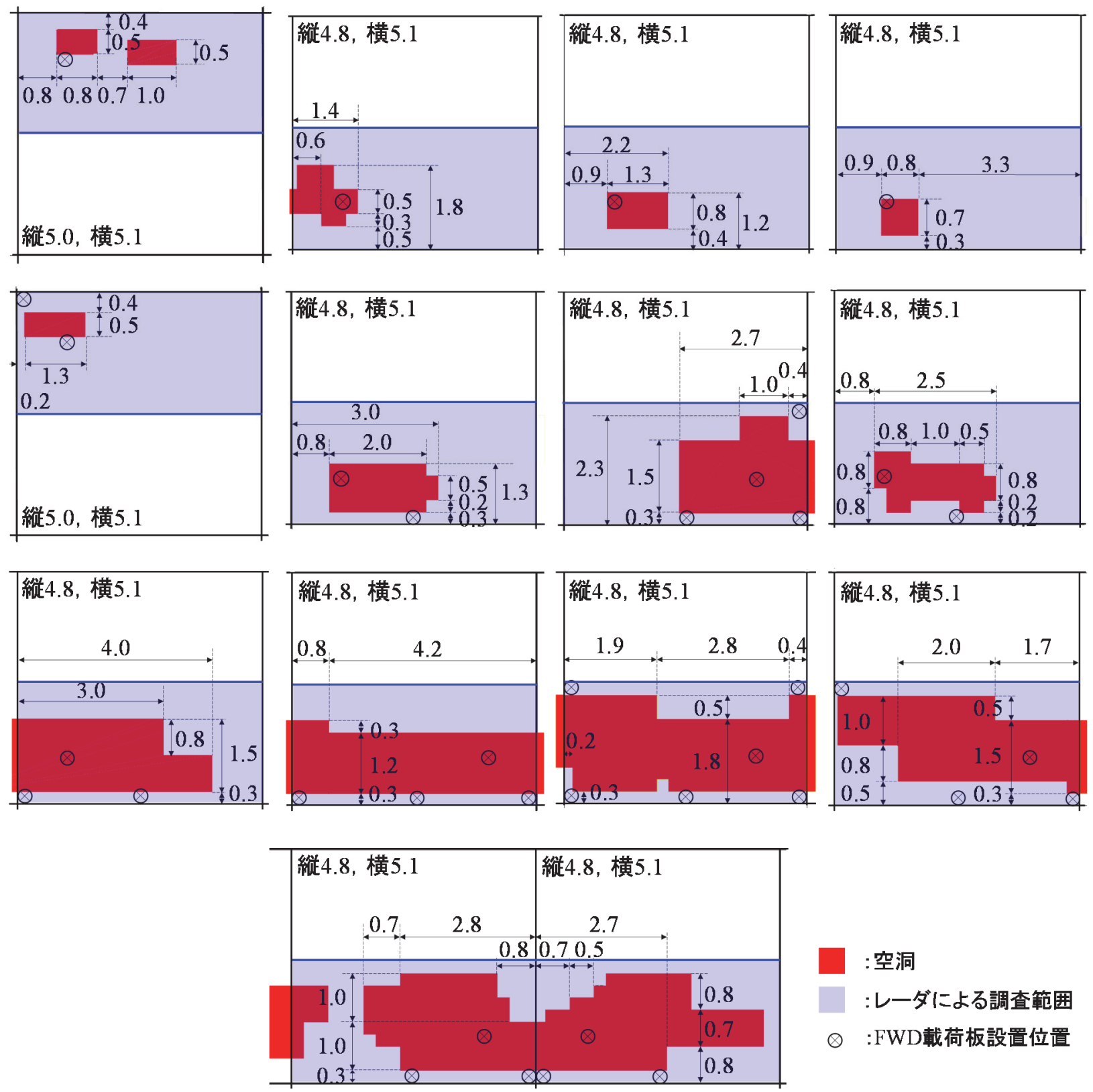

図-11 空洞版群の各版における空洞平面分布（単位：m）

下に空洞が確認された版 14 枚（以下，空洞版群）につい て，正規化たわみとたわみ時間差を指標とした空洞検出 の適用性を検証した．また，レーダで空洞が確認されな かった版 10 枚 (以下, 非空洞版群) を比較の対象とした.

レーダによる判定結果の確認のため, 図-11 の 14 枚中 3 枚の版において, 赤塗り範囲で 1 か所ずつコアボーリ ングにより削孔調査を行い，全位置で版直下の空洞（厚 さ $0.20 〜 0.25 \mathrm{~m}$ ）を確認した．選定した全 24 枚には宿没 およびひび割れは生じていない.

\section{(3) FWD 調査}

\section{a) 載荷条件}

載荷板直径は $0.3 \mathrm{~m}$ であり, 載荷荷重は $147 \mathrm{kN}$ である.
載荷は同一位置にて 4 回行い，載荷 1 回目のデータを棄 却した。なお，調査の制約から載荷 2 回目のみ，時刻歴

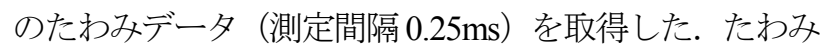
の測定点は, 載荷板中心，中心より 200，300，450，600， 750，900，1200，1500 および $2000 \mathrm{~mm}$ である.

\section{b) 載荷板設置位置}

図-12に, FWD の載荷板設置位置とたわみセンサの配 置方向の模式図を示す，載荷板は，目地部，隅角から縦 横 $1.0 \mathrm{~m}$ の位置（以下，隅角近傍部）および隅角部に設置 した. 図-11 には空洞版群における実際の載荷板設置位 置を示した。 なお，隅角近傍部では，空洞版群の寸べて において載荷板が空洞直上となる.

本調査では，調査中の気温差は小さかったことから 
$\left(9.7^{\circ} \mathrm{C} \sim 12.5^{\circ} \mathrm{C}\right)$ ，選定した版ごとの温度勾配とそれに 伴う反りの程度に大差はないと考えられるため, 版ごと の温度勾配が異なることによるたわみの温度補正は行っ ていない，また，調査は冬季の昼間であり，版が反って いたとしても上にロの変形であるため，版の反りが目地 付近のたわみに及ぼす影響は小さいと考えられる.

\section{(4) FWD 調査結果}

以下では, 目地部, 隅角近傍部および隅角部について, 空洞版群と非空洞版群の正規化たわみ，もしくは，たわ み時間差を比較する.

\section{a) 目地部}

図-13 に載荷板中心から測定点までの距離と正規化た わみの関係を示し，図-14 には載荷板中心から測定点ま
での距離とたわみ時間差の関係を示す．測定点までの距 離によらず，空洞版群の方が正規化たわみの平均值は大 きく，たわみ時間差の平均值は小さかった.

図-15に, 測定点 $300 \mathrm{~mm}$ および $1500 \mathrm{~mm}$ における正規 化たわみとたわみ時間差の関係を一例として示す. 300mm では空洞版群と非空洞版群の 2 群の分布に明確 な違いは確認されなかった. $1500 \mathrm{~mm}$ では空洞版群の分 布は相対的に左上方に位置した.

ここで，全測定点について 2 群間の正規化たわみの平 均差およびたわ及時間差の平均差に関する検定を行った。 表-2 に結果を示す. 正規化たわみの平均差は全測定点で 有意であり，たわみ時間差の平均差は 450mm 以上の測 定点で有意であった. $300 \mathrm{~mm}$ 以内の測定点においてたわ み時間差に有意差が確認されなかった要因として，たわ

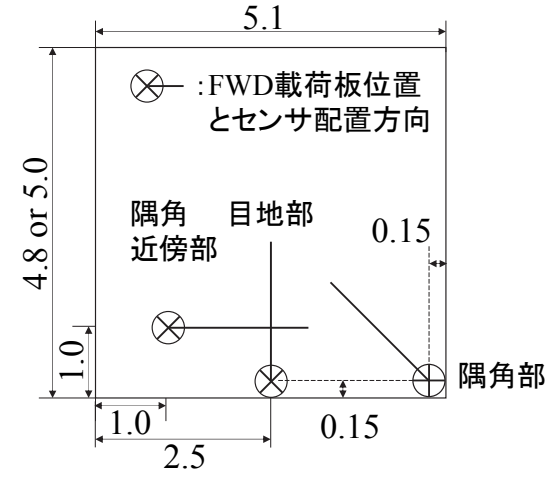

図-12＼cjkstart載荷板設置位置とたわみセンサの配置方向

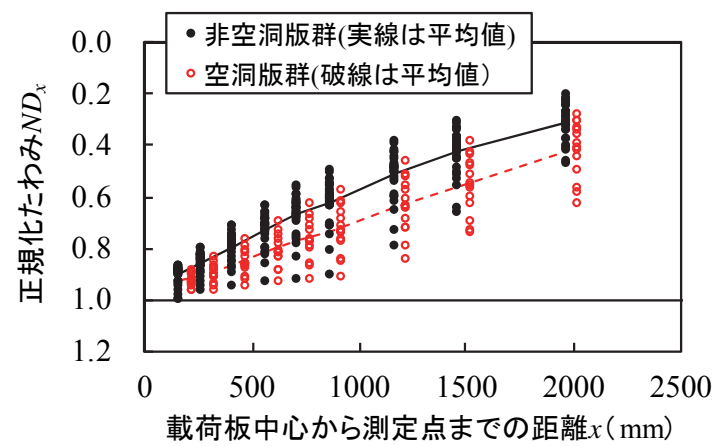

図-13 目地部の正規化たわみ

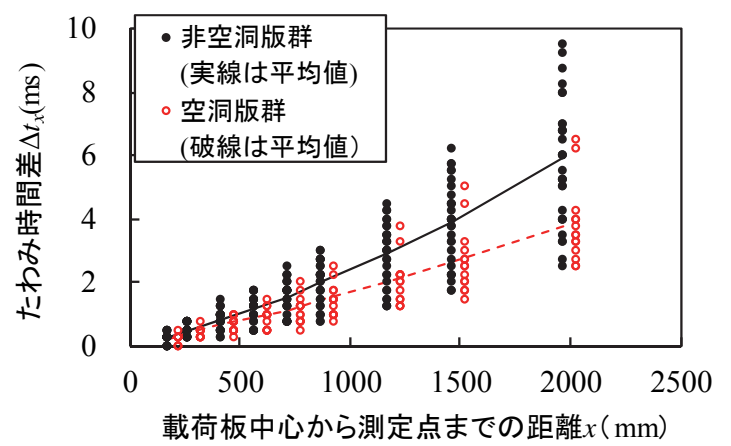

図-14 目地部のたわみ時間差

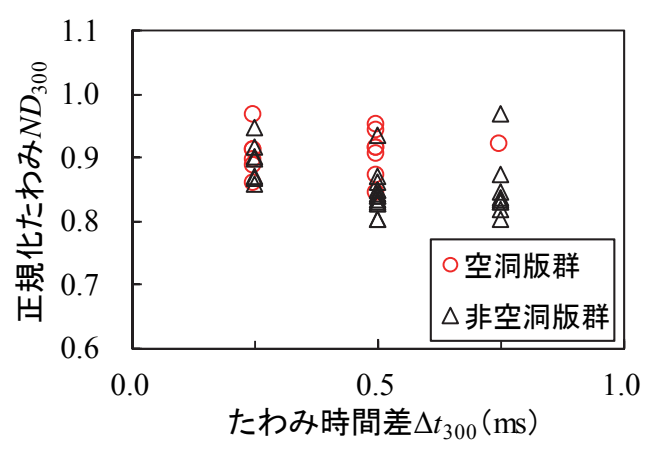

a) 測定点 $300 \mathrm{~mm}$

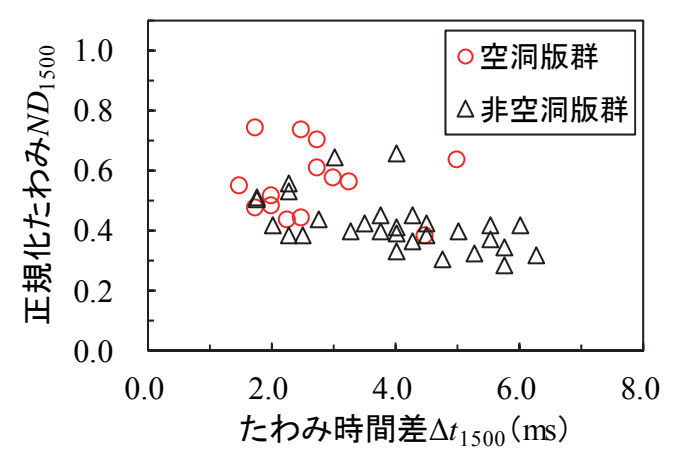

b) 測定点 $1500 \mathrm{~mm}$

図-15 目地部の正規化たわみとたわみ時間差の関係

表-2＼cjkstart目地部の空洞版群と非空洞版群間の各指標の平 均差に関する検定結果（有意水準 5\%)

\begin{tabular}{|l|l|} 
a) & \multicolumn{1}{|c|}{ 規化たわみ } \\
\hline & 検定結果 \\
\hline$N D_{200}$ & p値 $<0.05$ :有意 \\
\hline$N D_{300}$ & p値 $<0.05$ :有意 \\
\hline$N D_{450}$ & p値 $<0.05$ :有意 \\
\hline$N D_{600}$ & p値 $<0.05$ :有意 \\
\hline$N D_{750}$ & p値 $<0.05$ :有意 \\
\hline$N D_{900}$ & p値 $<0.05$ :有意 \\
\hline$N D_{1200}$ & p値 $<0.05$ :有意 \\
\hline$N D_{1500}$ & p値 $<0.05$ :有意 \\
\hline$N D_{2000}$ & p値 $<0.05$ :有意 \\
\hline
\end{tabular}

b) たわみ時間差

\begin{tabular}{|c|c|}
\hline & 検定結果 \\
\hline$\Delta t_{200}$ & $\mathrm{p}$ 值 $>0.05$ \\
\hline$\Delta t_{300}$ & $\mathrm{p}$ 值 $>0.05$ \\
\hline$\Delta t_{450}$ & $\mathrm{p}$ 值 $<0.05$ : 有意 \\
\hline$\Delta t_{600}$ & p值 $<0.05$ : 有意 \\
\hline$\Delta t_{750}$ & $\mathrm{p}$ 值 $<0.05$ : 有意 \\
\hline$\Delta t_{900}$ & p値 $<0.05$ : 有意 \\
\hline$\Delta t_{1200}$ & $\mathrm{p}$ 値 $<0.05$ : 有意 \\
\hline$\Delta t_{1500}$ & p值 $<0.05$ : 有意 \\
\hline & :有意 \\
\hline
\end{tabular}


み時間差がサンプリング間隔 $(0.25 \mathrm{~ms})$ に近い 0.25 $0.75 \mathrm{~ms}$ であったためと考えられる。

\section{b) 隅角近傍部}

図-16 に, 測定点 300mm および $1500 \mathrm{~mm}$ における正規 化たわみとたわみ時間差の関係を一例として示す. 300mm，1500mm ともに，2 群間の正規化たわみには明 確な違いは確認されなかったが，たわみ時間差では空洞 版群が小さい傾向であつた.

ここで，全測定点について 2 群間の各指標の平均差に 関する検定を行った．表-3に結果を示す．正規化たわみ の平均差は，全測定点で有意でなかった。一方，たわみ 時間差の平均差は, $200 \mathrm{~mm}$ 以外の測定点で有意であった. これより，たわみ時間差は正規化たわみよりも空洞の存

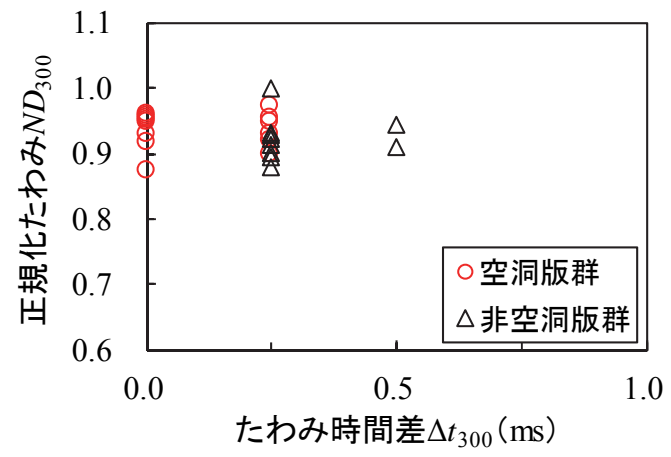

a) 測定点 $300 \mathrm{~mm}$

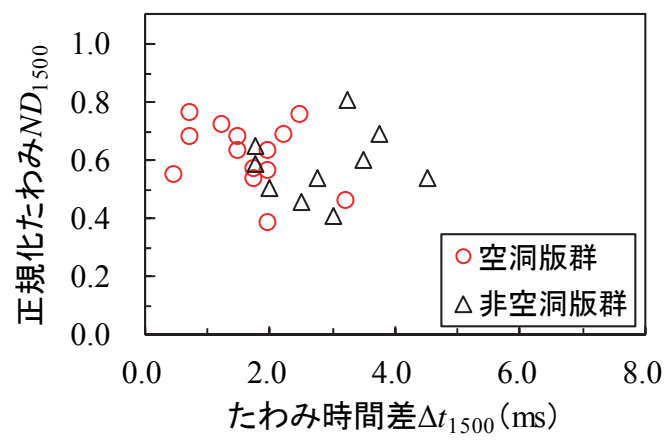

b) 測定点 $1500 \mathrm{~mm}$

図-16 隅角近傍部の正規化たわみとたわみ時間差の関係

表-3 隅角近傍部の空洞版群と非空洞版群間の各指標の 平均差に関する検定結果 (有意水準 5\%) a) 正規化たわみ

\begin{tabular}{|l|l|}
\hline & 検定結果 \\
\hline \hline$N D_{200}$ & p値 $>0.05$ \\
\hline$N D_{300}$ & p値 $>0.05$ \\
\hline$N D_{450}$ & p値 $>0.05$ \\
\hline$N D_{600}$ & p値 $>0.05$ \\
\hline$N D_{750}$ & p 值 $>0.05$ \\
\hline$N D_{900}$ & p值 $>0.05$ \\
\hline$N D_{1200}$ & p値 $>0.05$ \\
\hline$N D_{1500}$ & p値 $>0.05$ \\
\hline$N D_{2000}$ & p値 $>0.05$ \\
\hline
\end{tabular}

b) たわみ時間差

\begin{tabular}{|c|c|}
\hline & 検定結果 \\
\hline$\Delta t_{200}$ & $\mathrm{p}$ 值 $>0.05$ \\
\hline$\Delta t_{300}$ & $\mathrm{p}$ 值 $<0.05$ :有意 \\
\hline$\Delta t_{450}$ & $\mathrm{p}$ 值 $<0.05$ :有意 \\
\hline$\Delta t_{600}$ & $\mathrm{p}$ 值 $<0.05$ :有意 \\
\hline$\Delta t_{750}$ & p値 $<0.05$ :有意 \\
\hline$\Delta t_{900}$ & $\mathrm{p}$ 值 $<0.05$ : 有意 \\
\hline$\Delta t_{1200}$ & $\mathrm{p}$ 值 $<0.05$ : 有意 \\
\hline$\Delta t_{1500}$ & $\mathrm{p}$ 值 $<0.05$ :有意 \\
\hline$\Delta t_{2000}$ & p值 $<0.05$ : 有意 \\
\hline
\end{tabular}

在に対して鋭敏であると示唆される.

\section{c) 隅角部}

図-17 に, 測定点 $300 \mathrm{~mm}$ および $1500 \mathrm{~mm}$ の正規化たわ みとたわみ時間差の関係を示す. $300 \mathrm{~mm}$ と $1500 \mathrm{~mm}$ は, それぞれ目地部の傾向と同様であった.

ここで，全測定点について 2 群間の各指標の平均差に 関する検定を行った．表-4に結果を示す．正規化たわみ の平均差は $1500 \mathrm{~mm}$ 以下の測定点で有意であり，たわみ 時間差の平均差は $450 \mathrm{~mm}$ 以上の測定点で有意であった.

\section{(5) 調査結果の分析}

a) FWD の結果に基づく空洞有無の追加確認

レーダで空洞があると判定された版と空洞がないと判

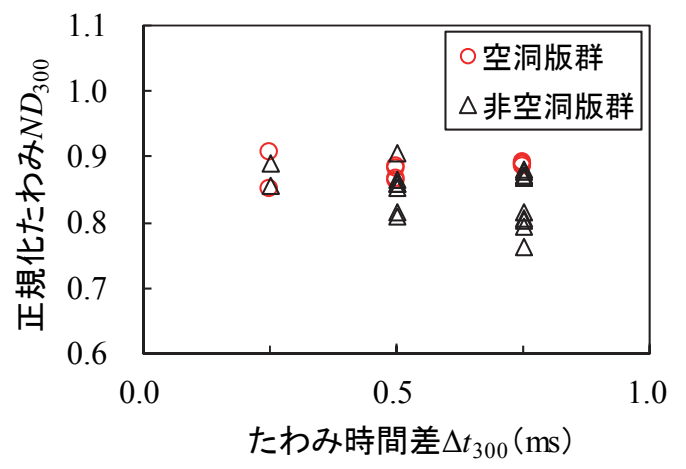

a) 測定点 $300 \mathrm{~mm}$

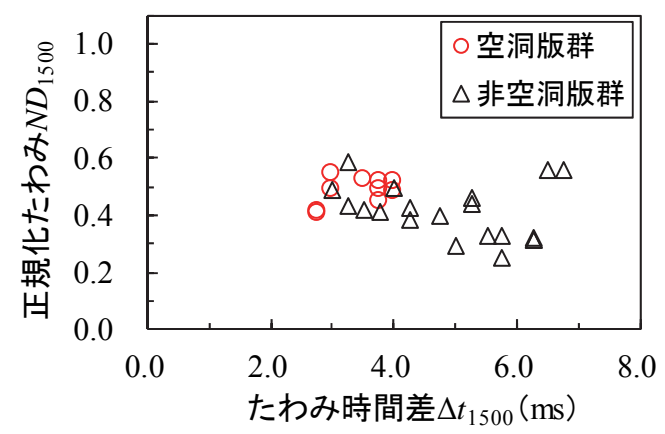

b) 測定点 $1500 \mathrm{~mm}$

図-17 隅角部の正規化たわみとたわみ時間差の関係

表-4 隅角部の空洞版群と非空洞版群間の各指標の平均 差に関する検定結果 (有意水準 5\%)

a) 正規化たわみ

\begin{tabular}{|l|l|}
\hline & 検定結果 \\
\hline \hline$N D_{200}$ & p値 $<0.05$ :有意 \\
\hline$N D_{300}$ & p値 $<0.05$ :有意 \\
\hline$N D_{450}$ & p値 $<0.05$ :有意 \\
\hline$N D_{600}$ & p値 $<0.05$ :有意 \\
\hline$N D_{750}$ & p値 $<0.05$ :有意 \\
\hline$N D_{900}$ & p値 $<0.05$ :有意 \\
\hline$N D_{1200}$ & p値 $<0.05$ :有意 \\
\hline$N D_{1500}$ & p値 $<0.05$ :有意 \\
\hline$N D_{2000}$ & p値 $>0.05$ \\
\hline
\end{tabular}

b) たわみ時間差

\begin{tabular}{|l|l|}
\hline & 検定結果 \\
\hline \hline$\Delta t_{200}$ & $\mathrm{p}$ 値 $>0.05$ \\
\hline$\Delta t_{300}$ & $\mathrm{p}$ 值 $>0.05$ \\
\hline$\Delta t_{450}$ & $\mathrm{p}$ 值 $<0.05$ : 有意 \\
\hline$\Delta t_{600}$ & $\mathrm{p}$ 值 $<0.05$ : 有意 \\
\hline$\Delta t_{750}$ & $\mathrm{p}$ 值 $<0.05$ :有意 \\
\hline$\Delta t_{900}$ & $\mathrm{p}$ 值 $<0.05$ :有意 \\
\hline$\Delta t_{1200}$ & $\mathrm{p}$ 值 $<0.05$ :有意 \\
\hline$\Delta t_{1500}$ & $\mathrm{p}$ 值 $<0.05$ :有意 \\
\hline$\Delta t_{2000}$ & $\mathrm{p}$ 值 $<0.05$ :有意 \\
\hline
\end{tabular}


定された版において，正規化たわみおよびたわみ時間差 が同様の值を示す版が確認された（例えば，図-15 b)の $\Delta t_{1500}$ が 1.5 3.0ms 付近). 正規化たわみとたわみ時間差 の関係を考慮すると，それらの版のレーダによる判定結 果は，実際の空洞有無と異なる可能性も考えられる.

そこで，非空洞版群のうち，図-15 b)で $\Delta t_{1500}$ が 1.5 3.0ms であった 4 枚の版の目地部において削孔調査 を追加で実施し，空洞有無を確認した.

図-18 に調査結果を示す. 4 枚ともに空洞が確認され た. 空洞厚さは 3 枚で $0.01 \sim 0.02 \mathrm{~m}, 1$ 枚で $0.10 \mathrm{~m}$ であ り，空洞版群における削孔調査で確認された空洞厚さよ りも薄かった。このことから，正規化たわみおよびたわ み時間差の関係を削孔調査の結果と照らし合わせること で, $0.01 \mathrm{~m}$ 程度の厚さの空洞も検出できる可能性がある.

\section{b) 空洞寸法と各種指標の関連性}

正規化たわみやたわみ時間差と，空洞の平面寸法の間 に相関があれば，空洞の有無だけでなく，その寸法も推 測できる可能性がある。 そこで，各指標とレーダで判定 された空洞の平面寸法の関係を調べた.

図-19 に隅角近傍部の正規化たわみ $N D_{1500}$ およびたわ み時間差 $\Delta t_{1500}$ と，センサ配置方向の空洞の長さとの関 係を示す，空洞が長くなると，正規化たわみは大きくな り，たわみ時間差は小さくなる傾向であるが，決定係数 $R^{2}$ では各指標と空洞の長さの間に相間があるとは言え ない，本調査の範囲においては，正規化たわみやたわみ 時間差によって，空洞の大きさを推定することは困難で あると考えられる。

(6) 正規化たわみとたわみ時間差の空洞検出指標とし ての適用性考察

a) 正規化たわみおよびたわみ時間差と $D_{0}$ の空洞検出 感度の比較

正規化たわみやたわみ時間差が，既往研究で空洞検出

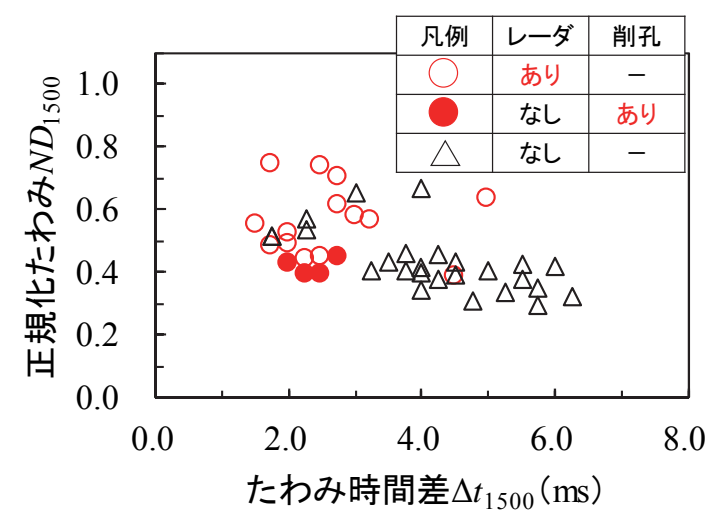

図-18 目地部の正規化たわみ $N D_{1500}$ とたわみ時間差 $\Delta t 1500$ の関係（追加の削孔調査で確認後）
指標として検討された $D_{0}$ よりも, 空洞の存在により影響 を受けやすい指標であることを確認するために，空洞版 群と非空洞版群間の補正 $D_{0}$ の平均差に関しても検定を 行い，その結果を，前述した正規化たわみやたわみ時間 差に関する検定結果と比較することとした.

表-5 に補正 $D_{0}$ に関する検定結果と，表-2, 3, 4 に示し た検定結果のうち，測定点 $1500 \mathrm{~mm}$ における正規化たわ みとたわみ時間差の結果を一例として示す.

補正 $D_{0}$ では，目地部，隅角近傍部および隅角部のいず れでも有意差を確認できなかった。一方，正規化たわみ およびたわみ時間差については，目地部，隅角近傍部お よび隅角部の殆どで，空洞版群と非空洞版群間で有意差 が確認された.このことから，正規化たわみおよびたわ み時間差の方が，空洞と非空洞で差が表れやすく，空洞 の存在により影響を受けや寸い指標であると考えられる. ただし, 測定点 $300 \mathrm{~mm}$ のように, 載荷板中心から近い

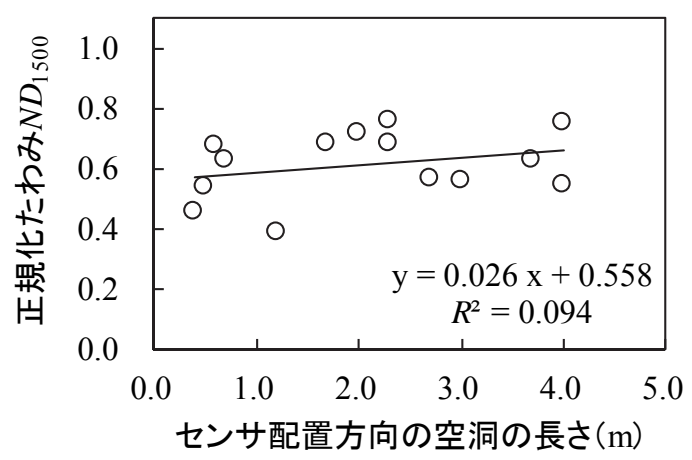

a) 正規化たわみ $N D 1500$

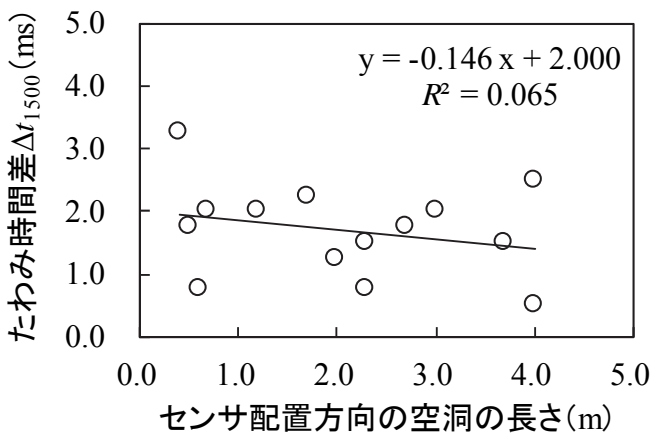

b) たわみ時間差 $\Delta t_{1500}$

図-19 センサ配置方向の空洞の長さと各指標の関係

表-5 空洞版群と非空洞版群間の補正 $D_{0}$, 正規化たわみ, または,たわみ時間差の平均差に関する検定結果 (有 意水準 5\%)

\begin{tabular}{|c|c|c|c|}
\hline & 目地部 & 隅角近傍部 & 隅角部 \\
\hline 補正 $D_{0}$ & $\mathrm{p}$ 値 $>0.05$ & $\mathrm{p}$ 值 $>0.05$ & $\mathrm{p}$ 值 $>0.05$ \\
\hline$N D_{1500}$ & $\mathrm{p}$ 值 $<0.05$ : 有意 & $\mathrm{p}$ 值 $>0.05$ & $\mathrm{p}$ 值 $<0.05$ : 有意 \\
\hline$\Delta t_{1500}$ & $\mathrm{p}$ 值 $<0.05$ : 有意 & $\mathrm{p}$ 值 $<0.05$ : 有意 & $\mathrm{p}$ 值 $<0.05$ : 有意 \\
\hline
\end{tabular}


測定点のたわみ時間差では, サンプリング間隔 $(0.25 \mathrm{~ms})$ に近くなり，空洞と非空洞箇所で差が表れ難くなる可能 性があることに留意する必要がある.

\section{b) 適用可能箇所}

2 章および 3 章の調査結果に基づくと，正規化たわみ は，版中央部，目地部および隅角部に位置寸る空洞の存 在により変化し,たわみ時間差については, 上記に加え, 隅角近傍部に位置する空洞でも変化した.このことから, 2 つ指標を複合的に用いる空洞検出は，版中央部，目 地部，隅角近傍部および隅角部において適用できると考 えられる。

また，空港舗装での版厚は $0.42 \mathrm{~m}$ であり，港湾舗装で の版厚は $0.25 \mathrm{~m}$ であったことから, 本方法は一般的なコ ンクリート舗装の版厚であれば，版厚によらず適用でき る可能性がある.

\section{4. まとめ}

空洞を有する空港および港湾コンクリート舗装で FWD 調査を実施し，版下の空洞が舗装の応答に及ぼす 影響を分析した。その結果をまとめると以下の通りであ る.

(1) 空洞の存在により正規化たわみは大きく，たわみ時 間差は小さくなることを示した. これら 2 指標は, $D_{0}$ よりも版直下の空洞の存在により影響を受けや寸い 指標であると考えられる.

（2）正規化たわみとたわみ時間差を複合的に用いる空洞 検出方法は, 版中央部, 目地部, 隅角近傍部および隅 角部において適用できると考えられる. また, 本方法 は一般的なコンクリート舗装の版厚であれば，版厚 によらず適用できる可能性がある。

（3）載荷板中心からたわみ測定点までの距離が $300 \mathrm{~mm}$ 程 度でのたわ及時間差は，サンプリング間隔に近くな り，空洞と非空洞箇所で差が表れ難くなる可能性が ある。

(4) センサの配置方向の空洞の長さが $0.4 \mathrm{~m}$ から $4.0 \mathrm{~m}$ の 範囲では, 空洞の長さと,たわみ時間差や正規化たわ みの間に相関を確認できなかった．本研究の範囲で は，たわみ時間差やたわみ時間差によって空洞の長 さを推定することは困難であると考えられる.

(5) レーダでは空洞がないと判定された版でも，実際に は空洞がある場合があり，正規化たわみおよびたわ み時間差の関係と, 削孔調査の結果を照らし合わせ ることで，空洞があると判定できる可能性がある.

\section{5. おわりに}

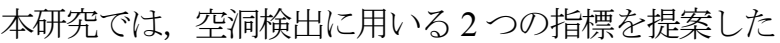
が，2 指標に関する空洞検出のための閾値の設定方法は

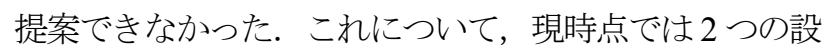
定方法を考えている.

1 つは，2 章で実施した解析のように，評価の対象とす る舗装各層の厚さや材料定数を用いて時刻歴のたわみ波 形を解析的に求め, 正規化たわ久やたわ久時間差を導出 し，それらを閾值とする方法である。

もう 1 つは，正規化たわみおよびたわみ時間差の関係 と, 削孔調査の結果を照らし合わせて, 分布の境界線を 技術者が暫定的に設定する方法である.

今後，閾值の設定方法や設定した閾値による空洞判定 の正答率を検討することにより，2 指標を用いた空洞判 定方法の妥当性を検証する予定であるが，空洞の厚さや 大きさによっては判別しにくい中間的なデータがあるこ とは避けられないと考えられる. したがって，現時点で は本方法は, 空洞有無の可能性の一次スクリーニング手 法として活用できると考えられる.

\section{参考文献}

1) 坪川将丈，水上純一，畑伊織，前川亮太 : 東北地方太 平洋沖地震による仙台空港の舗装被害, 土木学会論文 集 E1 (舗装工学)，Vol. 68, No. 3, pp. I_123-I_129, 2012.

2) 田村敬一, 他 55 名 : 平成 19 年 (2007 年) 能登半島地 震被害調查報告，国土技術政策総合研究所資料，Vol. 438, pp. 1-243, 2008.

3) 佐藤徹, 加藤絵万, 川端雄一郎, 岡㟝慎一郎 : 港湾施 設の空洞化調査に関する報告 : 土木学会論文集 B3（海 洋開発)，Vol. 70, No. 2, pp. I_552-I_557, 2014.

4) 国土交通省航空局・国土交通省国土技術政策総合研究 所監修: 空港舗装補修要領及び設計例, (一財) 港湾空 港建設技術サービスセンター, 2011.

5) 元野一生, 今永繁, 藤田浩一, 島野好: 福岡県西方沖 地震における港湾施設の被災について, 海洋開発論文 集, Vol. 22, pp. 499-504, 2006.

6) 八谷好高, 坂井典和, 廣田道紀, 高橋修 : $200 \mathrm{kN}$ 荷重 の FWD による空港コンクリート舗装の非破壊構造評 価，土木学会舗装工学論文集，pp. 199-208, 1999.

7) Sheng, Z., Jia, X. and Xiaojun, Z. : Analysis on criterion for void identifying under cement concrete pavement corner, In: New Technologies in Construction and Rehabilitation of Portland Cement Concrete Pavement and Bridge Deck Pavement, pp. 125-132, 2009.

8） FWD 研究会: 2000 年度報告書「FWD に関する研究」, 2000.

9) 城本政一, 青木政樹, 竹内康 : 小型 FWD と地中レー ダを併用した路面下空洞調査方法に関する検討路, 土 木学会論文集 E1 (舗装工学), Vol. 69, No. 3, pp. I_167I 173, 2013.

10) 土木学会舗装工学委員会: FWD および小型 FWD 運用 の手引き，（社）土木学会，2002.

11）小澤良明，松井邦人：フォークトモデルで構成された 
舗装構造の波動伝播解析，土木学会論文集 E, Vol. 64, No. 2, pp. 314-322, 2008.

12) 竹内康, 小梁川雅, 牧恒雄, 丸山暉彦, 木村慎 : コン クリート舗装における路盤 $\mathrm{K}$ 值と弾性係数の換算式 に関する実験的研究，土木学会論文集 E, Vol. 50, No.
669, pp. 17-25, 2001.

13）土木学会舗装工学委員会 : 非破壊試験による舗装のた わみ測定と構造評価，（社）土木学会，2015.

(2016. 9. 16 受付)

\title{
DETECTION METHOD OF VOIDS UNDER CONCRETE SLAB BY USING FWD
}

\author{
Naoya KAWAMURA, Yukitomo TSUBOKAWA and Ema KATO
}

This paper proposes a method for detecting void that occurred under concrete pavement slab on the basis of pavement's response gained from Falling Weight Deflectometer (FWD). FWD tests were carried out on airport and port concrete pavements that have voids under their concrete slabs. Then, the test results were analyzed to clarify influences of void on the response of concrete pavement. As a result, the authors found out that two index: normalized deflection and peak time difference of deflection can be used for detecting voids underneath concrete slabs, which were more sophisticated indexes to detect void when they were compared with maximum deflection of the center of loading plate. The two indexes are applicable to any thickness of concrete slab and in any distance from concrete joint. 